\title{
Cellular and molecular mechanisms involved in the establishment of HIV-1 latency
}

Daniel A Donahue ${ }^{1,2}$ and Mark A Wainberg ${ }^{1,2^{*}}$

\begin{abstract}
Latently infected cells represent the major barrier to either a sterilizing or a functional HIV-1 cure. Multiple approaches to reactivation and depletion of the latent reservoir have been attempted clinically, but full depletion of this compartment remains a long-term goal. Compared to the mechanisms involved in the maintenance of HIV-1 latency and the pathways leading to viral reactivation, less is known about the establishment of latent infection. This review focuses on how HIV-1 latency is established at the cellular and molecular levels. We first discuss how latent infection can be established following infection of an activated CD4 T-cell that undergoes a transition to a resting memory state and also how direct infection of a resting CD4 T-cell can lead to latency. Various animal, primary cell, and cell line models also provide insights into this process and are discussed with respect to the routes of infection that result in latency. A number of molecular mechanisms that are active at both transcriptional and post-transcriptional levels have been associated with HIV-1 latency. Many, but not all of these, help to drive the establishment of latent infection, and we review the evidence in favor of or against each mechanism specifically with regard to the establishment of latency. We also discuss the role of immediate silent integration of viral DNA versus silencing of initially active infections. Finally, we discuss potential approaches aimed at limiting the establishment of latent infection.
\end{abstract}

Keywords: Latency, CD4 T-cell, Reservoir, Establishment, Transcriptional interference, Epigenetics, Chromatin

\section{Review}

Latently infected cells represent the major obstacle to either a sterilizing or a functional HIV-1 cure. HIV-1 latency can be defined as a reversibly nonproductive infection of a cell [1], which is usually interpreted to refer to an integrated provirus that is replication-competent but transcriptionally silent. In light of recent evidence, this definition might be expanded to include proviruses that express some but not all gene products in the absence of virion production [2-5]. The latent reservoir is established very early after infection [6,7], and reactivation of latently infected cells serves as a major source of viral rebound upon treatment failure [8,9]. Recent studies of the dynamics of viral load decay have shown the presence of two kinetically distinct latent reservoirs, i.e. the sources of plasma viremia during the third and fourth phases of decay $[7,10,11]$, potentially representing

\footnotetext{
* Correspondence: mark.wainberg@mail.mcgill.ca

${ }^{1}$ McGill University AIDS Centre, Lady Davis Institute, Jewish General Hospital, Montreal, Québec, Canada

${ }^{2}$ Department of Microbiology and Immunology, McGill University, Montreal, Québec, Canada
}

different memory CD4 T-cell subsets. Multiple approaches to reactivation and depletion of the latent reservoir have been attempted clinically (summarized in $[12,13]$ ), and these efforts aim to reactivate latently infected cells so as to render them susceptible to viral cytopathic effects, an antiviral immune response, or other means of targeted cell killing $[14,15]$. However, complete depletion of the latent reservoir remains a long-term goal.

Although much attention is deservedly paid to defining how latency is maintained and how latent viruses can be reactivated, the mechanisms involved in the establishment of latency are incompletely understood. Given that the latent reservoir can be replenished during infection [16,17], a deeper knowledge of how latency is established would be invaluable. This review focuses on how HIV-1 latency is established at the cellular and molecular levels, and discusses potential approaches to limit the establishment of latent reservoirs. 
A. Generation of memory CD4 T-cells
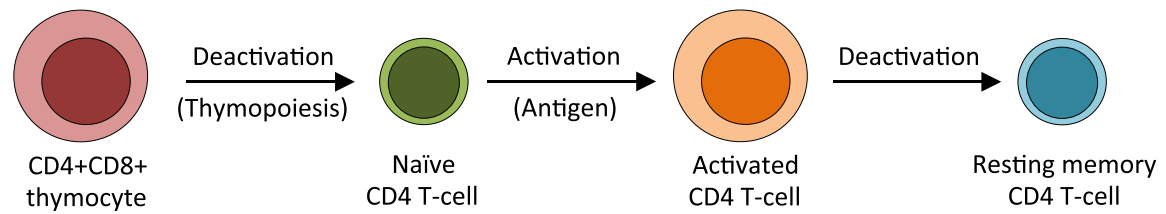

B. Infection during deactivation

C. Direct resting cell infection

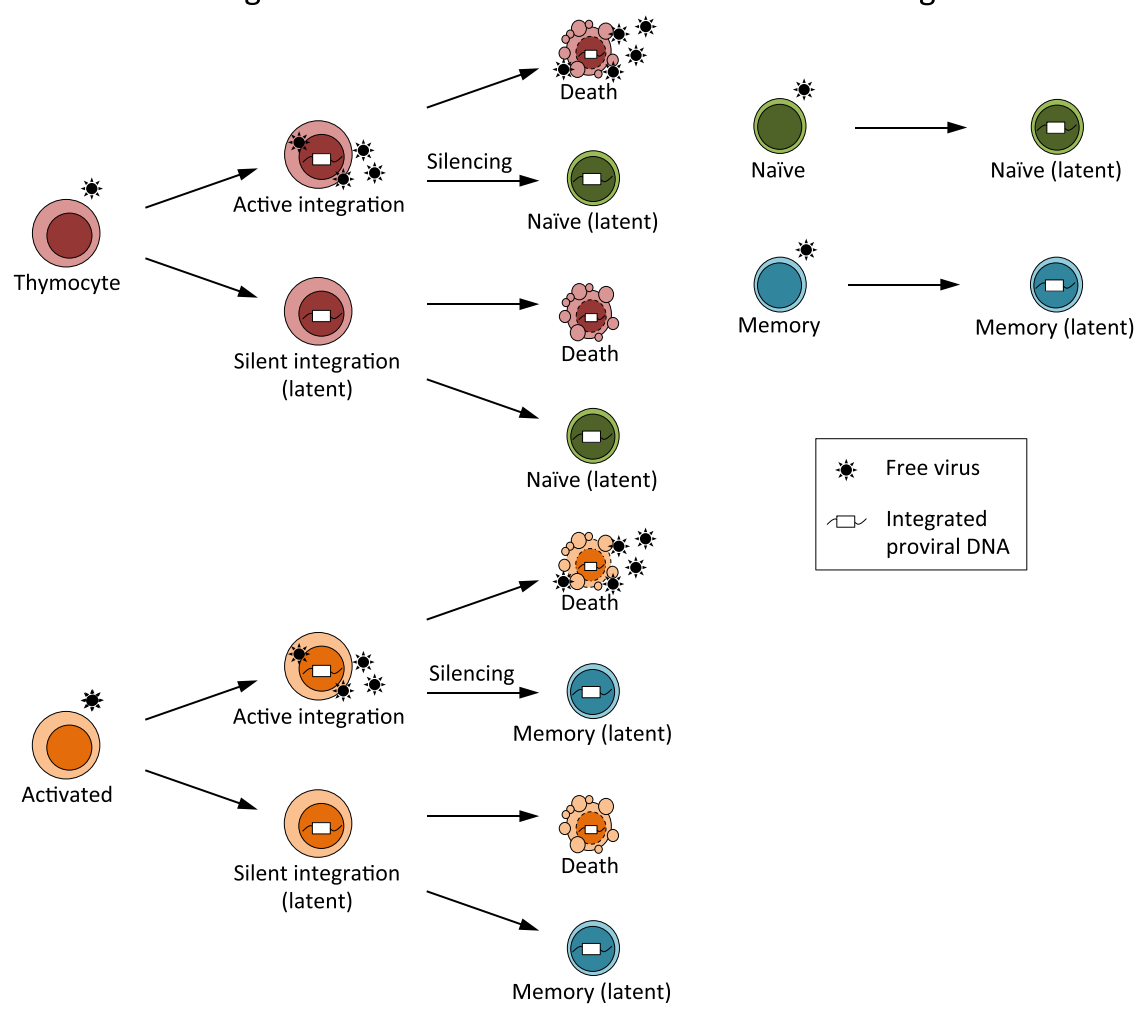

Figure 1 Cellular pathways of the establishment of HIV-1 latency in CD4 T-cells. (A) Generation of memory CD4 T-cells. Transcriptionally active CD4+CD8+ (double positive) thymocytes transition to a resting state upon completion of thymopoiesis to become resting naïve CD4 Tcells. Naïve cells are activated upon encounter with antigen-bearing dendritic cells and undergo rapid clonal expansion. A small fraction of activated CD4 T-cells survive and transition to a resting state, to become resting memory CD4 T-cells. (B) Infection during deactivation. Infection of an activated thymocyte can result in active integration or immediate silent integration. Latency can be established upon the transition to a naïve CD4 T-cell. Infection of an activated CD4 T-cell can result in active integration or immediate silent integration. Latency can be established upon the transition to a resting memory CD4 T-cell. Note that for immediate silent integration into an activated thymocyte or an activated CD4 T-cell, latency has already been established at the virological level. Due to the rapid deaths of activated cells, only cells which transition to a resting state represent clinically relevant latent infections. (C) Direct resting cell infection. Infection of a naïve CD4 T-cell, or of a resting memory CD4 T-cell, results in immediate silent integration, i.e., latency. Note that the relative contributions of the pathways shown here are not known.

\section{Establishment of HIV-1 latency at the cellular level}

Although the pathways leading to latent virus reactivation can be studied ex vivo, it is not possible to study the establishment of latency in this manner, since by definition latency has already been established in any latently infected cells that can be isolated from an infected individual. Nonetheless, studies that investigate which subsets of resting cells harbor integrated virus in patients can be instructive, since knowledge of cellular physiology can shed light on how latent infection might have been established in a given cell type. Latently infected resting memory CD4 T-cells form the largest reservoir and represent the reservoir of greatest clinical importance due to their long lifespan [1]. Although it is likely that latency can occur in other cell types (reviewed in [1,18-20]), this review primarily focuses on the establishment of latency in CD4 T-cells.

\section{Multiple CD4 T-cell subsets}

Naïve CD4 T-cells are activated by interaction with dendritic cells (DC) that present an appropriate antigen. These activated T-cells then rapidly proliferate and differentiate 
into several subsets of effectors including Th1, Th2, Th17 and inducible regulatory T-cells [21]. While the majority of effector cells rapidly die, a small minority will survive and undergo a transition to a resting state as memory CD4 T-cells. Memory CD4 T-cells, which provide for an enhanced immune response upon future encounter with the same antigen, are likely derived from all effector subsets [22]. In addition, memory CD4 T-cells are themselves composed of several subsets that probably represent a gradient of separate maturational stages [23]. Central memory cells $\left(\mathrm{T}_{\mathrm{CM}}\right)$ migrate to secondary lymphoid organs where they can be activated by DCs to generate multiple waves of secondary effector cells. Effector memory cells $\left(\mathrm{T}_{\mathrm{EM}}\right)$ are likely derived from $\mathrm{T}_{\mathrm{CM}}$, and are found in peripheral tissues, where they can act almost immediately as secondary effectors upon activation at sites of inflammation. Transitional memory cells $\left(\mathrm{T}_{\mathrm{TM}}\right)$ represent an intermediate cell type that possesses a phenotype intermediary between $\mathrm{T}_{\mathrm{CM}}$ and $\mathrm{T}_{\mathrm{EM}}$ [23-26]. Thus, the term "activated" CD4 T-cell can refer to either a primary effector cell that resulted from activation of a naive cell, or to a secondary effector cell that resulted from activation of a memory cell. Similarly, the term "resting" CD4 T-cell can either refer to a naïve cell or to a memory cell. Resting cells can be distinguished from activated cells by their small size, low RNA content, non-cycling status, and lack of activation markers such as CD69, CD25 and HLA-DR [27].

\section{Infection during deactivation vs. direct infection of resting cells}

HIV-1 latency can arise in CD4 T-cells from infection of an activated effector cell that undergoes a reversion to a resting state during the process of memory cell generation (referred to herein as "infection during deactivation"), or from infection of a resting cell (direct resting cell infection), as illustrated in Figure 1. If latency is established during deactivation, then latent virus should be found mainly in memory cells. Conversely, direct infection of resting cells could result in latent virus being present in either naïve or memory cells. These pathways are not mutually exclusive. Latency can also be established during the deactivation process associated with thymopoiesis (discussed below), which would also result in latently infected naïve T-cells.

Infection of resting CD4 T-cells is inefficient due to many factors including low CCR5 expression [28], cytoskeletal barriers [29], limiting levels of deoxynucleoside triphosphates (dNTPs) [30,31] due to SAMHD1 [32,33], and inefficient nuclear import and integration [30,34]. In vitro, direct infection of naïve CD4 T-cells is less efficient than direct infection of memory CD4 T-cells $[35,36]$. This is because naïve cells have low to undetectable levels of CCR5 expression [28,37,38]; fusion is also less efficient in naïve cells [39], and cortical actin dynamics are lower compared to memory cells [40].
Several studies have examined the distribution of HIV1 provirus in resting CD4 T-cells from peripheral blood and lymphoid tissues of patients. While some reports identified integrated DNA only in memory cells [41], most others have shown that memory cells constitute the major reservoir but that naïve cells harbour lower provirus levels [35,38,42-46]. In one recent study of patients on suppressive therapy, $98 \%$ of all proviruscontaining CD4 T-cells were memory cells (of these, $52 \%$ were $\mathrm{T}_{\mathrm{CM}}, 34 \%$ were $\mathrm{T}_{\mathrm{TM}}$ and $14 \%$ were $\mathrm{T}_{\mathrm{EM}}$ ), and only $2 \%$ were naïve cells [45]. In simian immunodeficiency virus (SIV)-infected rhesus macaques, most infected cells identified during early infection (i.e. the time of reservoir formation) were found to be resting CD4 T-cells [47]. Furthermore, cytokine/chemokine rich microenvironments in lymphoid tissues can aid infection of resting cells [48-51], and chemokine treatment of resting cells can lead to the establishment of latency in vitro $[3,52,53]$. It is, therefore, possible that the contribution of direct resting cell infection to the establishment of latency is greater than is commonly appreciated. Given that HIV-1 preferentially infects activated CD4 Tcells $[30,34]$, coupled with the ongoing generation of memory cells, the consensus is that infection prior to or during deactivation is the major route of establishment of latency, although this remains an unresolved issue.

\section{Routes of latency establishment: in vivo models}

SIV-infected macaques receiving suppressive antiretroviral therapy are now excellent models to better understand the role of tissue reservoirs, sanctuary sites, viral dynamics in response to therapy, and in vivo testing of eradication strategies (reviewed in [54]). Humanized mouse models of HIV-1 latency are also useful and include severe combined immunodeficient humanized thymus/liver (SCID-hu Thy/Liv) mice [55], NOD/ SCID-gamma chain null (NSG) bone marrow-liverthymus (BLT) mice $[56,57]$ and $\operatorname{Rag} 2^{-1-} \gamma_{c}^{-1-}$ mice [58]. In SCID-hu (Thy/Liv) mice, latent infection is established during thymopoiesis, leading to generation of latently infected naïve T-cells. Thymopoiesis mirrors the generation of memory $\mathrm{T}$-cells, since transcriptionally active immature $\mathrm{CD} 4+\mathrm{CD} 8+$ thymocytes enter a quiescent state upon maturation to naïve T-cells (Figure 1A). Therefore, the establishment of latency during thymopoiesis [55] is an example of latency arising from infection during deactivation. Latent virus was also identified in purified resting CD4 T-cells [57] and in naïve lymphocytes [56] of infected BLT mice, and in central memory CD4 T-cells of infected $\operatorname{Rag} 2^{-1-} \gamma_{c}^{-/-}$ mice [58]. Collectively, these studies suggest that both infection during deactivation and direct infection of resting cells likely contribute to the establishment of latency in vivo. 


\section{Routes of latency establishment: in vitro models}

Several primary cell latency models have been established (for detailed comparisons see [59-63]). Some of these models involve infection of activated CD4 T-cells that are allowed to return to a resting state through various culture conditions [64-69], with latency established in $1 \%$ to $75 \%$ of cells depending on the system. Several other models involve direct infection of either untreated or chemokine-treated resting CD4 T-cells [52,70-72] and result in up to a few percent of cells becoming latently infected, reflecting the preferential infection of activated cells. Taken together, these models demonstrate that both pathways can give rise to latency under appropriate conditions.

One report described the establishment of latency in multiple subsets of CD34+ hematopoietic progenitor cells (HPCs) derived from either bone marrow or umbilical cord blood [73]. In this model, purified HPCs are infected shortly after isolation and latency is established within a few days, in a manner analogous to direct infection of resting CD4 T-cells. Although the detection of HIV-1 DNA in HPCs from patients on suppressive highly active antiretroviral therapy (HAART) is controversial [74-77], it is clear that latency can be established in HPCs in vitro [73,75] (reviewed in [78]). While a latently infected HPC could theoretically give rise to other types of latently infected cells in vivo, including CD4 Tcells, it is unlikely that the virus would remain in a latent state during HPC differentiation [75].

Finally, a number of reports have described models of latency establishment at a population level in CD4 T-cell lines, including Jurkat [79-84], SupT1 $[85,86]$ and Molt-4 [81] cells. The establishment of latency in proliferating cell lines implies that latency might be established in some fraction of infected, activated CD4 T-cells, even in vivo (included schematically in Figure 1B). However, the short lifespan of activated cells in vivo [87] implies that any such latent infections would be clinically irrelevant. Having examined how latency is established in terms of cellular physiology, we now turn our focus to the molecular level.

\section{Molecular mechanisms of the establishment of HIV-1 latency}

The mechanisms associated with latency, particularly its maintenance and reactivation, have been extensively reviewed (for recent reviews see [63,88-91]). These mechanisms include transcriptional interference, insufficient levels of transcriptional activators, the presence of transcriptional repressors, epigenetics, nucleosome positioning, insufficient Tat activity, blocks to mRNA splicing or nuclear export, cellular microRNA (miRNA), and homeostatic proliferation of latently infected cells. While each of these is known to be involved in the maintenance of latency, here we discuss which of these mechanisms have been shown to promote viral entry into latency (summarized in Table 1). Homeostatic proliferation is an important mechanism of survival of resting CD4 T-cells that can be induced by homeostatic cytokines including IL-7 and IL-15 [92]. Since its role in maintaining latently infected cells occurs, by definition, after latency has been established, and in keeping with the focus of this review, homeostatic proliferation is not discussed here as a mechanism of establishment of latency.

\section{Transcriptional interference}

HIV-1 preferentially integrates into the introns of actively expressed genes in CD4 T-cell lines [93,94], and both activated and resting primary CD4 T-cells that are infected ex vivo [95-97]. Initial studies in the Jurkatbased J-LAT system found that integration into both heterochromatin [79,98] and highly expressed genes [98] was associated with latency. Proviruses in resting CD4 T-cells from patients on HAART were also shown to be integrated into highly expressed genes, with no preference for orientation relative to the host gene [99]. A consequence of integration into regions of high transcriptional activity is transcriptional interference, a process whereby transcription that originates at one promoter can interfere with transcription at another (reviewed in $[100,101])$. One study found that convergently oriented integration resulted in transcriptional interference that silenced $\mathrm{HIV}-1$ gene expression in a TNF- $\alpha$-reversible manner [102], and similar findings were obtained in a Jurkat latency establishment model [68]. Another study found that transcriptional interference was responsible for latency in Jurkat and primary CD4 T-cells [103]. Transcriptional interference was also recently linked to the establishment of latency following viral integration into highly expressed genes in Jurkat cells, and the authors showed a role for chromatin reassembly factors in the maintenance of latency via transcriptional interference [104]. Finally, transcriptional interference contributed to the establishment of latency in a primary cell model, in which latent but not active proviruses had an orientation bias with respect to the host gene [97]. Although it is difficult to differentiate between roles for transcriptional interference in the establishment versus the maintenance of latency [81,104], most evidence suggests that both can occur depending on the host cell chromosomal context.

\section{Limited availability of transcription factors}

A hallmark of quiescent lymphocytes is the low availability of transcriptional activators, either due to cytoplasmic sequestration, or regulation of protein levels or activity. This includes the transcription factors NF- $\mathrm{B}$ and NFAT, which recruit histone acetyltransferases [63] 
Table 1 Mechanisms of latency establishment

\begin{tabular}{|c|c|c|}
\hline \multirow{2}{*}{$\begin{array}{l}\text { Mechanisms associated with } \\
\text { latency }\end{array}$} & \multicolumn{2}{|c|}{ Evidence for a role in establishing latency in: } \\
\hline & Cell line models ${ }^{a}$ & Primary cell models ${ }^{\mathrm{a}}$ \\
\hline Transcriptional interference & Yes $^{\mathrm{b}}[68,102,104]$ & Yes [97] \\
\hline Limiting transcription factors & Yes $[81,84,106]^{*}$ & Yes [81] \\
\hline Limiting P-TEFb & $?^{c}$ & Yes $[69,109]$ \\
\hline Transcriptional repressors & $?$ & $?$ \\
\hline \multirow[t]{2}{*}{ Histone deacetylation } & Yes [113] & \multirow[t]{2}{*}{ Yes [69] } \\
\hline & $\mathrm{No}^{\mathrm{d}}[81]$ & \\
\hline Histone methylation & Yes $[111,112,114,115]$ & Yes [69] \\
\hline DNA methylation & No [81] & $?$ \\
\hline Nucleosome positioning & Yes [117] & $?$ \\
\hline Insufficient Tat activity & Yes $[82,83,113,114,121]$ & Yes [69] \\
\hline Insufficient mRNA nuclear export & $?$ & Yes [3] \\
\hline Insufficient mRNA splicing & $?$ & Yes [4] \\
\hline miRNA & $?$ & $?$ \\
\hline Homeostatic proliferation & $?$ & $?$ \\
\hline
\end{tabular}

${ }^{a}$ Only studies that explicitly examined the establishment of latency are included.

${ }^{b}$ Yes: This mechanism has been shown to influence the establishment of latency.

c ?: The effects of this mechanism on the establishment of latency have not been studied.

${ }^{d}$ No: This mechanism has been shown to not influence the establishment of latency.

* In [106] transcription factors may not be limiting, but altered the establishment of latency.

and aid transcription initiation, and are critical for viral transcription. Both NF- $\mathrm{kB}$ and NFAT are sequestered in the cytoplasm in the absence of activation signals, in part due to the protein Murr1 in the case of NF- $\mathrm{kB}$ [105]. In one study, the establishment of latency in Jurkat cells was found to result from low levels of active $\mathrm{NF}-\mathrm{kB}$ at the time of infection, and only cell lines with low basal levels of NF-kB activity supported the establishment of latency. Furthermore, the induction of NF$\kappa \mathrm{B}$ nuclear translocation by pre-treatment of Jurkat cells with phorbol myristate acetate (PMA) or prostratin, or of primary cells with phytohemagglutinin (PHA), strongly inhibited the establishment of latency [81]. Another group found that $\mathrm{Sp} 1$ or $\mathrm{kB}$ site mutations $(\kappa \mathrm{B}$ sites can be occupied by both NF-kB and NFAT) in the 5 ' long terminal repeat (LTR) led to higher levels of latency [84]. In a model of latency establishment in CD34+ HPCs, nuclear levels of NF-kB were low at the time of infection but were increased upon stimulation and subsequent reactivation of latent virus [73].

It has recently been reported that the establishment of latency in a polyclonal population of Jurkat reporter cells was regulated by an AP-1 binding site in the 5' LTR [106]. Deletion of this site severely limited the establishment of latency. Conversely, extension of this site from 4 to 7 nucleotides (as found in HIV-1 subtypes A and C) had no effect on initial latency levels but resulted in significantly greater levels of latency after several weeks of culture, likely due to lower rates of spontaneous reactivation of latent viruses carrying the 7 nucleotide sequence [106]. While this study does not necessarily provide evidence for a role of AP-1 in the establishment of latency, it suggests that variations in interactions involving transcription factors can have profound effects on the establishment of latency. Finally, it has been hypothesized that immunosuppressive cytokines including IL-10 and transforming growth factor beta (TGF- $\beta$ ) might indirectly aid the establishment of latency by reducing levels of T-cell activation [107], although this remains speculative.

\section{Limited availability of elongation factors}

The elongation factor P-TEFb is composed of Cyclin T1 and CDK9, and converts promoter-proximally paused RNA polymerase II complexes into efficient elongating complexes [90]. In many cell types P-TEFb is sequestered in the cytoplasm in a complex containing 7SK snRNA, HEXIM1, and other components [108], and a study using a primary cell latency model found that low $\mathrm{P}-\mathrm{TEFb}$ levels contributed to latency establishment [69]. However, a recent study found that P-TEFb availability in both naïve and memory CD4 T-cells is regulated by tight control of Cyclin $\mathrm{T} 1$ levels (by proteasomemediated proteolysis and microRNA regulation) and CDK9 T-loop phosphorylation (where only Thr-186phosphorylated CDK9 is active), and not by the 7SK snRNA complex. The authors also showed that levels of Cyclin T1 and Thr-186-phosphorylated CDK9 decreased sharply during the transition of activated CD4 T-cells to central memory cells, during which time latency was 
established [109]. Thus, multiple mechanisms of transcriptional activator insufficiency can contribute to the establishment of latency.

\section{Chromatin modifications}

Epigenetic modifications dictate which proteins can interact with chromatin, and alter the physical structure of chromatin [110]. Proviral silencing after single-round infection of both Jurkat cells [111] and microglial cells [112] was shown to be mediated by the histone H3 lysine 9 (H3K9) methyltransferase Suv39H1 and its partner HP1 $\gamma$. Entry into latency in Jurkat cells was associated with CBF-1-dependent histone deacetylase (HDAC)-1 recruitment to the 5' LTR [113], and H3K9/ 27 trimethylation [114]. Furthermore, CBF-1-dependent H3 deacetylation, followed by Suv39H1- and HP1 $\alpha$ dependent $\mathrm{H} 3 \mathrm{~K} 9 / 27$ trimethylation, led to the establishment of latency in primary cells [69]. Interestingly, CBF-1 is expressed in resting CD4 T-cells but is strongly downregulated upon T-cell activation [113]. Most recently, this group has demonstrated a role for the H3K27 methyltransferase EZH2, a component of the polycomb repressive complex 2, in establishing latency in Jurkat cells [115]. However, a different study found no evidence for histone deacetylation in the establishment of latency, since pre-treatment of Jurkat cells with the HDAC inhibitor valproic acid did not reduce the number of latently infected cells that were established [81].

DNA methylation at CpG islands is a repressive epigenetic modification that can inhibit transcription factor binding and can recruit HDAC-2. The available evidence suggests that DNA methylation is a later silencing event that is more important for the maintenance of HIV-1 latency than for its establishment $[89,116]$. Additionally, one study showed that pre-treatment of Jurkat cells with the DNA methylation inhibitor 5-azacytidine did not inhibit the establishment of latency [81]. Finally, the SWI/ SNF chromatin remodeling complex BAF, but not PBAF, was recently shown to facilitate the establishment of latency through repressive nucleosome positioning on the 5' LTR. BAF knockdown resulted in fewer latent infections in both Jurkat and SupT1 T-cell lines, without affecting levels of productively infected cells [117]. The evidence therefore supports a major role for epigenetic histone modifications and chromatin remodeling leading to provirus silencing and the establishment of latent infection.

\section{Insufficient Tat activity}

Since Tat is required for high-level viral transcription, due to recruitment of a super elongation complex to the 5 ' LTR $[118,119]$, it is perhaps unsurprising that insufficient Tat activity can lead to the establishment of latency. In one study, resting CD4 T-cells from treated patients were enriched for attenuated Tat variants [120]. Mutations that attenuated Tat activity led to higher levels of latency establishment in both Jurkat $[82,113,114]$ and primary cell [69] models. Treatment of Jurkat cells with Tat at the time of infection led to a subsequent decrease in the frequency of latently infected cells [82]. Further, expression of Tat in trans prevented the silencing of actively infected cells [114] and strongly inhibited the establishment of latency in Jurkat cells [82]. Finally, random fluctuations in Tat concentrations at the single cell level were shown to influence the entry of HIV-1 into latency, as shown in mathematical models and experimentally $[83,121]$. Based on these findings, proteins that modulate Tat activity might be expected to impact the establishment of latency, as has been suggested for Tat acetylation via SirT1 [121].

\section{Post-transcriptional mechanisms}

Multiply spliced mRNA was found in the nucleus, but not in the cytoplasm, of resting CD4 T-cells from HAARTtreated patients. This block was shown to be due to low levels of polypyrimidine tract binding protein (PTB), the overexpression of which rescued multiply spliced mRNA nuclear export and virus production [2]. However, it was unclear whether limiting PTB levels contributed to the initial establishment of latency. In a primary cell model in which resting cells are directly infected after chemokine treatment [52], it was shown that multiply spliced mRNA accumulated in the nucleus but not the cytoplasm, in the absence of other transcripts or viral proteins [3]. In another resting cell model of latency establishment, [70] a block to mRNA splicing was recently identified, whereby latently infected cells produced Gag protein (at levels 1000-fold lower than in activated cells) but only barely detectable levels of Env. This result was reflected at the mRNA level, since unspliced transcripts were $\sim 100$-fold more abundant than singly spliced transcripts and 10,000-fold more abundant than multiply spliced transcripts [4]. Together, these primary cell models highlight two post-transcriptional blocks that contribute to the establishment of latency. In addition, miRNA regulation of viral protein expression has been associated with latency, and several of the miRNAs that have been implicated in this process are expressed in resting cells but are downregulated upon T-cell activation. Although miRNAs can contribute to the maintenance of latency, as shown both in vitro and ex vivo [122,123], the potential role of miRNAs in the establishment of latency remains unknown [124].

Silencing of active infection vs. immediate silent integration It is unclear whether latency is established by the silencing of active infection or by the immediate silent integration of viral DNA (Figure 1B-C). Several in vitro 
studies have examined these alternatives, and additional information can be gathered from close analysis of cell culture models of latency establishment. First, it should be noted that evidence in favor of one route of latency establishment does not necessarily exclude the other. Some Jurkat [114] and primary cell [67,69] models involve cell sorting for active infections that are then cultured and allowed to become latent, demonstrating that the silencing of active infections can lead to the establishment of latency. In these reports some viral proteins were mutated to prevent their expression, resulting in reduced cytotoxicity, which might have allowed cells to survive long enough in order for silencing to occur. One study provided evidence for silencing of active infections in both CEM and primary cells, without the use of cell sorting and with replication-competent virus [125].

Several other groups have provided evidence for immediate silent integration. For example, J-LAT cells were derived by sorting GFP-negative cells shortly after infection with a reporter construct [79]. Additional studies in CD4 T-cell lines have provided evidence for silent integration leading to latency, sometimes by showing reactivation of latent virus as early as one day post-infection $[81,82,86,106,126]$. Data from a primary cell model in which cells are infected during the transition to a resting state suggest that latency occurred largely by silent integration [66]. Finally, all published latency models that depend on direct infection of resting cells have shown immediate silent integration [3,70-72]. Thus, silencing of active infection, and immediate silent integration, both contribute to the establishment of latency in vitro, and direct infection of resting cells consistently results in immediate silent integration. If, however, the majority of latent infections in vivo arise from infection prior to or during cellular deactivation, the pathway of latency establishment is likely to depend on how far along the deactivation process a given cell is at the time of infection.

\section{Prospects for inhibition of the establishment of latency}

Depletion of the latent reservoir is a major goal of the field, and this might be complemented by strategies aimed at limiting the establishment of latent infections. Whether the establishment of latent reservoirs can be inhibited in patients is an important issue in the quest for a functional cure [127]. This has been examined in vitro, through studies in which treatment of Jurkat cells with exogenous Tat protein led to a reduction in the establishment of latency [82]. A novel approach has recently been proposed which would involve interference with chemokine-induced establishment of latency. In this scenario, treatment with chemokine receptor antagonists or engineered 'dominant negative' chemokines would inhibit the establishment of latent infections that result from direct infection of resting cells [128]. Several clinical studies have observed that very early initiation of HAART can lead to the establishment of smaller latent reservoirs than are observed if treatment is started later [7,45,129-132]. It remains to be determined whether early treatment with compounds that counteract pathways of the establishment of latency merits clinical consideration.

\section{Conclusions}

The establishment of HIV-1 latency is a complex process, which likely results from the convergence of multiple mechanisms (Table 1). The relative importance of these mechanisms is probably dependent on the physiological state of the cell undergoing infection (Figure 1). Are findings in cell line models of establishment of latency reproducible in primary cell models? Although they often are, it also appears that not all mechanisms involved in the establishment of latency play a role in cell lines. For example, it has been proposed that epigenetic silencing might have a greater role in cell lines than in primary cells [71], since several other mechanisms of establishment of latency, including limited availability of transcription factors, P-TEFb, and the nuclear export factor PTB are mainly associated with quiescent cells and might be less important in actively dividing cells. Are different mechanisms of silencing required depending on the pathway of latency establishment, i.e. infection during deactivation vs. direct resting cell infection, or latency resulting from silencing of active infection vs. immediate silent integration? Although this is an open question, the evidence suggests that these different routes of establishment of latency can all occur under different circumstances.

It is not yet known whether the establishment of latency might differ between memory $\mathrm{CD} 4 \mathrm{~T}$-cell subsets, for example in $\mathrm{T}_{\mathrm{CM}}$ compared to $\mathrm{T}_{\mathrm{TM}}$. Additionally, little is known about how latency can be established in other cell types, which might exhibit important differences compared to CD4 T-cells. It is also unclear how well the different models of latency establishment recapitulate this process in patients. Which primary cell model(s) might reflect the in vivo establishment of latency most accurately? The answers to this and related questions await a better understanding of the mechanisms and routes of latency establishment under in vivo conditions. Finally, the feasibility of pharmacological interventions that would limit the establishment of latent reservoirs, and any potential clinical benefits this might entail, remain important unanswered questions.

Competing interests

The authors declare that they have no competing interests. 


\section{Authors' contributions}

DAD wrote the manuscript. MAW modified parts of the manuscript in his role as Head of the Laboratory. Both authors read and approved the final manuscript.

\section{Acknowledgements}

This work was funded by the Canadian Institutes of Health Research (CIHR) DAD is the recipient of a CIHR doctoral training award. We thank Dr. Richard D Sloan and Sophie M Bastarache for their help in reviewing the manuscript.

Received: 23 November 2012 Accepted: 4 January 2013

Published: 1 February 2013

\section{References}

1. Eisele $E$, Siliciano RF: Redefining the viral reservoirs that prevent HIV-1 eradication. Immunity 2012, 37:377-388.

2. Lassen KG, Ramyar KX, Bailey JR, Zhou Y, Siliciano RF: Nuclear retention of multiply spliced HIV-1 RNA in resting CD4+ T cells. PLoS Pathog 2006, 2:e68.

3. Saleh S, Wightman F, Ramanayake S, Alexander M, Kumar N, Khoury G, Pereira C, Purcell D, Cameron PU, Lewin SR: Expression and reactivation of HIV in a chemokine induced model of HIV latency in primary resting CD4+ T cells. Retrovirology 2011, 8:80

4. Pace MJ, Graf EH, Agosto LM, Mexas AM, Male F, Brady T, Bushman FD, O'Doherty U: Directly infected resting CD4+T cells can produce HIV gag without spreading infection in a model of HIV latency. PLoS Pathog 2012, 8:e1002818.

5. Fischer $M$, Joos B, Niederöst B, Kaiser $P$, Hafner R, Wyl von V, Ackermann M Weber R, Günthard HF: Biphasic decay kinetics suggest progressive slowing in turnover of latently HIV-1 infected cells during antiretroviral therapy. Retrovirology 2008, 5:107

6. Chun TW, Engel D, Berrey MM, Shea T, Corey L, Fauci AS: Early establishment of a pool of latently infected, resting CD4(+) T cells during primary HIV-1 infection. Proc Natl Acad Sci USA 1998, 95:8869-8873.

7. Archin NM, Vaidya NK, Kuruc JD, Liberty AL, Wiegand A, Kearney MF, Cohen MS, Coffin JM, Bosch RJ, Gay CL, Eron JJ, Margolis DM, Perelson AS: Immediate antiviral therapy appears to restrict resting CD4+ cell HIV-1 infection without accelerating the decay of latent infection. Proc Natl Acad Sci USA 2012, 109:9523-9528.

8. Joos B, Fischer M, Kuster H, Pillai SK, Wong JK, Böni J, Hirschel B, Weber R, Trkola A, Günthard HF, HIV Swiss Cohort Study: HIV rebounds from latently infected cells, rather than from continuing low-level replication. Proc Natl Acad Sci USA 2008, 105:16725-16730.

9. Zhang L, Chung C, Hu BS, He T, Guo Y, Kim AJ, Skulsky E, Jin X, Hurley A, Ramratnam B, Markowitz M, Ho DD: Genetic characterization of rebounding HIV-1 after cessation of highly active antiretroviral therapy. J Clin Invest 2000, 106:839-845.

10. Maldarelli F, Palmer S, King MS, Wiegand A, Polis MA, Mican J, Kovacs JA, Davey RT, Rock-Kress D, Dewar R, Liu S, Metcalf JA, Rehm C, Brun SC, Hanna GJ, Kempf DJ, Coffin JM, Mellors JW: ART suppresses plasma HIV-1 RNA to a stable set point predicted by pretherapy viremia. PLOS Pathog 2007, 3:e46.

11. Palmer S, Maldarelli F, Wiegand A, Bernstein B, Hanna GJ, Brun SC, Kempf DJ, Mellors JW, Coffin JM, King MS: Low-level viremia persists for at least 7 years in patients on suppressive antiretroviral therapy. Proc Natl Acad Sci USA 2008, 105:3879-3884.

12. Geeraert $L$, Kraus G, Pomerantz RJ: Hide-and-seek: the challenge of viral persistence in HIV-1 infection. Annu Rev Med 2008, 59:487-501.

13. Chun T-W, Fauci AS: HIV reservoirs: pathogenesis and obstacles to viral eradication and cure. AIDS 2012, 26:1261-1268.

14. Shan L, Deng K, Shroff NS, Durand CM, Rabi SA, Yang H-C, Zhang H, Margolick JB, Blankson JN, Siliciano RF: Stimulation of HIV-1-specific cytolytic T lymphocytes facilitates elimination of latent viral reservoir after virus reactivation. Immunity 2012, 36:491-501.

15. Berger EA: Targeted cytotoxic therapy: adapting a rapidly progressing anticancer paradigm for depletion of persistent HIV-infected cell reservoirs. Curr Opin HIV AIDS 2011, 6:80-85.

16. Chun T-W, Nickle DC, Justement JS, Large D, Semerjian A, Curlin ME, O'Shea MA, Hallahan CW, Daucher M, Ward DJ, Moir S, Mullins Jl, Kovacs C, Fauci AS: HIV-infected individuals receiving effective antiviral therapy for extended periods of time continually replenish their viral reservoir. J Clin Invest 2005, 115:3250-3255.

17. Rong L, Perelson AS: Modeling latently infected cell activation: viral and latent reservoir persistence, and viral blips in HIV-infected patients on potent therapy. PLoS Comput Biol 2009, 5:e1000533.

18. Redel L, Le Douce V, Cherrier T, Marban C, Janossy A, Aunis D, Van Lint C, Rohr O, Schwartz C: HIV-1 regulation of latency in the monocytemacrophage lineage and in CD4+ T lymphocytes. J Leukoc Biol 2010, 87:575-588

19. Coleman CM, Wu L: HIV interactions with monocytes and dendritic cells: viral latency and reservoirs. Retrovirology 2009, 6:51.

20. Le Douce V, Herbein G, Rohr O, Schwartz C: Molecular mechanisms of HIV1 persistence in the monocyte-macrophage lineage. Retrovirology 2010, 7:32.

21. Murphy KM, Stockinger B: Effector T cell plasticity: flexibility in the face of changing circumstances. Nat Immunol 2010, 11:674-680.

22. van Leeuwen EMM, Sprent J, Surh CD: Generation and maintenance of memory CD4(+) T Cells. Curr Opin Immunol 2009, 21:167-172.

23. Fritsch RD, Shen X, Sims GP, Hathcock KS, Hodes RJ, Lipsky PE: Stepwise differentiation of CD4 memory T cells defined by expression of CCR7 and CD27. J Immunol 2005, 175:6489-6497.

24. Riou C, Yassine-Diab B, Van grevenynghe J, Somogyi R, Greller LD, Gagnon D, Gimmig S, Wilkinson P, Shi Y, Cameron MJ, Campos-Gonzalez R, Balderas RS, Kelvin D, Sékaly R-P, Haddad EK: Convergence of TCR and cytokine signaling leads to $\mathrm{FOXO3a}$ phosphorylation and drives the survival of CD4+ central memory T cells. J Exp Med 2007, 204:79-91.

25. Sallusto F, Geginat J, Lanzavecchia A: Central memory and effector memory T cell subsets: function, generation, and maintenance. Annu Rev Immunol 2004, 22:745-763.

26. Rivino L, Messi M, Jarrossay D, Lanzavecchia A, Sallusto F, Geginat J: Chemokine receptor expression identifies Pre-T helper (Th)1, Pre-Th2, and nonpolarized cells among human CD4+ central memory T cells. J Exp Med 2004, 200:725-735

27. Vatakis DN, Nixon CC, Zack JA: Quiescent T cells and HIV: an unresolved relationship. Immunol Res 2010, 48:110-121

28. Bleul CC, Wu L, Hoxie JA, Springer TA, Mackay CR: The HIV coreceptors CXCR4 and CCR5 are differentially expressed and regulated on human T lymphocytes. Proc Natl Acad Sci USA 1997, 94:1925-1930.

29. Spear M, Guo J, Wu Y: The trinity of the cortical actin in the initiation of HIV-1 infection. Retrovirology 2012, 9:45.

30. Zack JA, Arrigo SJ, Weitsman SR, Go AS, Haislip A, Chen IS: HIV-1 entry into quiescent primary lymphocytes: molecular analysis reveals a labile, latent viral structure. Cell 1990, 61:213-222.

31. Meyerhans A, Vartanian JP, Hultgren C, Plikat U, Karlsson A, Wang L, Eriksson S. Wain-Hobson S: Restriction and enhancement of human immunodeficiency virus type 1 replication by modulation of intracellular deoxynucleoside triphosphate pools. J Virol 1994, 68:535-540.

32. Descours B, Cribier A, Chable-Bessia C, Ayinde D, Rice G, Crow Y, Yatim A, Schawartz O, Laquette N, Benkirane M: SAMHD1 restricts HIV-1 reverse transcription in quiescent CD4+ T-cells. Retrovirology 2012, 9:87.

33. Baldauf H-M, Pan X, Erikson E, Schmidt S, Daddacha W, Burggraf M, Schenkova K, Ambiel I, Wabnitz G, Gramberg T, Panitz S, Flory E, Landau NR, Sertel S, Rutsch F, Lasitschka F, Kim B, König R, Fackler OT, Keppler OT: SAMHD1 restricts HIV-1 infection in resting CD4(+) T cells. Nat Med 2012, 18(11):1682-1687.

34. Stevenson M, Stanwick TL, Dempsey MP, Lamonica CA: HIV-1 replication is controlled at the level of T cell activation and proviral integration. EMBO J 1990, 9:1551-1560

35. Schnittman SM, Lane HC, Greenhouse J, Justement JS, Baseler M, Fauci AS: Preferential infection of CD4+ memory T cells by human immunodeficiency virus type 1: evidence for a role in the selective T-cell functional defects observed in infected individuals. Proc Natl Acad Sci USA 1990, 87:6058-6062

36. Woods TC, Roberts BD, Butera ST, Folks TM: Loss of inducible virus in CD45RA naive cells after human immunodeficiency virus-1 entry accounts for preferential viral replication in CD45RO memory cells. Blood 1997, 89:1635-1641.

37. Mo H, Monard S, Pollack H, Ip J, Rochford G, Wu L, Hoxie J, Borkowsky W, Ho DD, Moore JP: Expression patterns of the HIV type 1 coreceptors CCR5 and CXCR4 on CD4+ T cells and monocytes from cord and adult blood. AIDS Res Hum Retroviruses 1998, 14:607-617. 
38. Pierson T, Hoffman TL, Blankson J, Finzi D, Chadwick K, Margolick JB, Buck C, Siliciano JD, Doms RW, Siliciano RF: Characterization of chemokine receptor utilization of viruses in the latent reservoir for human immunodeficiency virus type 1. J Virol 2000, 74:7824-7833.

39. Dai J, Agosto LM, Baytop C, Yu JJ, Pace MJ, Liszewski MK, O'Doherty U: Human immunodeficiency virus integrates directly into naive resting CD4+ T cells but enters naive cells less efficiently than memory cells. J Virol 2009, 83:4528-4537.

40. Wang W, Guo J, Yu D, Vorster PJ, Chen W, Wu Y: A dichotomy in cortical actin and chemotactic actin activity between human memory and naive T cells contributes to their differential susceptibility to HIV-1 infection. J Biol Chem 2012, 287(42):35455-35469.

41. Chun TW, Carruth L, Finzi D, Shen X, DiGiuseppe JA, Taylor H, Hermankova M, Chadwick K, Margolick J, Quinn TC, Kuo YH, Brookmeyer R, Zeiger MA Barditch-Crovo P, Siliciano RF: Quantification of latent tissue reservoirs and total body viral load in HIV-1 infection. Nature 1997, 387:183-188.

42. Delobel $P$, Sandres-Sauné K, Cazabat M, L'Faqihi F-E, Aquilina C, Obadia M, Pasquier C, Marchou B, Massip P, Izopet J: Persistence of distinct HIV-1 populations in blood monocytes and naive and memory CD4 T cells during prolonged suppressive HAART. AIDS 2005, 19:1739-1750.

43. Ostrowski MA, Chun TW, Justement SJ, Motola I, Spinelli MA, Adelsberger J, Ehler LA, Mizell SB, Hallahan CW, Fauci AS: Both memory and CD45RA +/CD62L+ naive CD4(+) T cells are infected in human immunodeficiency virus type 1-infected individuals. J Virol 1999, 73:6430-6435.

44. Brenchley JM, Hill BJ, Ambrozak DR, Price DA, Guenaga FJ, Casazza JP, Kuruppu J, Yazdani J, Migueles SA, Connors M, Roederer M, Douek DC, Koup RA: T-cell subsets that harbor human immunodeficiency virus (HIV) in vivo: implications for HIV pathogenesis. J Virol 2004, 78:1160-1168.

45. Chomont N, El-Far M, Ancuta P, Trautmann L, Procopio FA, Yassine-Diab B, Boucher G, Boulassel M-R, Ghattas G, Brenchley JM, Schacker TW, Hill BJ, Douek DC, Routy J-P, Haddad EK, Sékaly R-P: HIV reservoir size and persistence are driven by $T$ cell survival and homeostatic proliferation. Nat Med 2009, 15:893-900

46. Wightman F, Solomon A, Khoury G, Green JA, Gray L, Gorry PR, Ho YS, Saksena NK, Hoy J, Crowe SM, Cameron PU, Lewin SR: Both CD31(+) and $\mathrm{CD}^{-} 1^{-}$naive CD4(+) T cells are persistent HIV type 1-infected reservoirs in individuals receiving antiretroviral therapy. J Infect Dis 2010, 202:17381748

47. Li Q, Duan L, Estes JD, Ma Z-M, Rourke T, Wang Y, Reilly C, Carlis J, Miller CJ, Haase AT: Peak SIV replication in resting memory CD4+ T cells depletes gut lamina propria CD4+ T cells. Nature 2005, 434:1148-1152.

48. Unutmaz D, KewalRamani VN, Marmon S, Littman DR: Cytokine signals are sufficient for HIV-1 infection of resting human T lymphocytes. J Exp Med 1999, 189:1735-1746

49. Kinter A, Moorthy A, Jackson R, Fauci AS: Productive HIV infection of resting CD4+ T cells: role of lymphoid tissue microenvironment and effect of immunomodulating agents. AIDS Res Hum Retroviruses 2003, 19:847-856

50. Eckstein DA, Penn ML, Korin YD, Scripture-Adams DD, Zack JA, Kreisberg JF, Roederer M, Sherman MP, Chin PS, Goldsmith MA: HIV-1 actively replicates in naive CD4(+) T cells residing within human lymphoid tissues. Immunity 2001, 15:671-682

51. Weissman D, Daucher J, Barker T, Adelsberger J, Baseler M, Fauci AS: Cytokine regulation of HIV replication induced by dendritic cell-CD4positive T cell interactions. AIDS Res Hum Retroviruses 1996, 12:759-767.

52. Saleh S, Solomon A, Wightman F, Xhilaga M, Cameron PU, Lewin SR: CCR7 ligands CCL19 and CCL21 increase permissiveness of resting memory CD4+ T cells to HIV-1 infection: a novel model of HIV-1 latency. Blood 2007, 110:4161-4164

53. Cameron PU, Saleh S, Sallmann G, Solomon A, Wightman F, Evans VA Boucher G, Haddad EK, Sékaly R-P, Harman AN, Anderson JL, Jones KL, Mak J, Cunningham AL, Jaworowski A, Lewin SR: Establishment of HIV-1 latency in resting $\mathrm{CD} 4+\mathrm{T}$ cells depends on chemokine-induced changes in the actin cytoskeleton. Proc Natl Acad Sci USA 2010, 107:16934-16939.

54. Deere JD, Schinazi RF, North TW: Simian immunodeficiency virus macaque models of HIV latency. Curr Opin HIV AIDS 2011, 6:57-61.

55. Brooks DG, Kitchen SG, Kitchen CM, Scripture-Adams DD, Zack JA: Generation of HIV latency during thymopoiesis. Nat Med 2001, 7:459-464.

56. Marsden MD, Kovochich M, Suree N, Shimizu S, Mehta R, Cortado R, Bristol G, An DS, Zack JA: HIV latency in the humanized BLT mouse. J Virol 2012, 86:339-347
57. Denton PW, Olesen R, Choudhary SK, Archin NM, Wahl A, Swanson MD, Chateau M, Nochi T, Krisko JF, Spagnuolo RA, Margolis DM, Garcia JV: Generation of HIV latency in humanized BLT mice. J Virol 2012, 86:630-634.

58. Choudhary SK, Archin NM, Cheema M, Dahl NP, Garcia JV, Margolis DM: Latent HIV-1 infection of resting $\mathrm{CD}^{+} \mathrm{T}$ cells in the humanized Rag2 $^{-} /{ }^{-} \mathrm{Yc}^{-} /$mouse. J Virol 2012, 86:114-120.

59. Tyagi M, Romerio F: Models of HIV-1 persistence in the CD4+ T cell compartment: past, present and future. Curr HIV Res 2011, 9:579-587.

60. Planelles $V$, Wolschendorf F, Kutsch O: Facts and fiction: cellular models for high throughput screening for HIV-1 reactivating drugs. Curr HIV Res 2011, 9:568-578.

61. Pace MJ, Agosto L, Graf EH, O'Doherty U: HIV reservoirs and latency models. Virology 2011, 411:344-354

62. Yang H-C: Primary cell models of HIV latency. Curr Opin HIV AIDS 2011, 6:62-67.

63. Hakre S, Chávez L, Shirakawa K, Verdin E: HIV latency: experimental systems and molecular models. FEMS Microbiol Rev 2012, 36:706-716.

64. Sahu GK, Lee K, Ji J, Braciale V, Baron S, Cloyd MW: A novel in vitro system to generate and study latently HIV-infected long-lived normal CD4+ Tlymphocytes. Virology 2006, 355:127-137.

65. Marini A, Harper JM, Romerio F: An in vitro system to model the establishment and reactivation of HIV-1 latency. J Immunol 2008, 181:7713-7720.

66. Bosque A, Planelles $\mathrm{V}$ : Induction of HIV-1 latency and reactivation in primary memory CD4+ T cells. Blood 2009, 113:58-65.

67. Yang H-C, Xing S, Shan L, O'Connell K, Dinoso J, Shen A, Zhou Y, Shrum CK, Han Y, Liu JO, Zhang H, Margolick JB, Siliciano RF: Small-molecule screening using a human primary cell model of HIV latency identifies compounds that reverse latency without cellular activation. J Clin Invest 2009, 119:3473-3486.

68. Burnett JC, Lim K-I, Calafi A, Rossi JJ, Schaffer DV, Arkin AP: Combinatorial latency reactivation for HIV-1 subtypes and variants. J Virol 2010, 84:5958-5974

69. Tyagi M, Pearson RJ, Karn J: Establishment of HIV latency in primary CD4+ cells is due to epigenetic transcriptional silencing and P-TEFb restriction. J Virol 2010, 84:6425-6437.

70. Swiggard WJ, Baytop C, Yu JJ, Dai J, Li C, Schretzenmair R, Theodosopoulos T, O'Doherty U: Human immunodeficiency virus type 1 can establish latent infection in resting CD4+ T cells in the absence of activating stimuli. J Virol 2005, 79:14179-14188.

71. Lassen KG, Hebbeler AM, Bhattacharyya D, Lobritz MA, Greene WC: A flexible model of HIV-1 latency permitting evaluation of many primary CD4 T-cell reservoirs. PLoS One 2012, 7:e30176.

72. Burke B, Brown HJ, Marsden MD, Bristol G, Vatakis DN, Zack JA: Primary cell model for activation-inducible human immunodeficiency virus. $J$ Virol 2007, 81:7424-7434.

73. McNamara LA, Ganesh JA, Collins KL: Latent HIV-1 infection occurs in multiple subsets of hematopoietic progenitor cells and is reversed by NF-KB activation. J Virol 2012, 86:9337-9350

74. Redd AD, Avalos A, Essex M: Infection of hematopoietic progenitor cells by HIV-1 subtype $C$, and its association with anemia in southern Africa. Blood 2007, 110:3143-3149.

75. Carter CC, Onafuwa-Nuga A, McNamara LA, Riddell J, Bixby D, Savona MR, Collins KL: HIV-1 infects multipotent progenitor cells causing cell death and establishing latent cellular reservoirs. Nat Med 2010, 16:446-451.

76. Durand CM, Ghiaur G, Siliciano JD, Rabi SA, Eisele EE, Salgado M, Shan L, Lai JF, Zhang H, Margolick J, Jones RJ, Gallant JE, Ambinder RF, Siliciano RF: HIV-1 DNA is detected in bone marrow populations containing CD4+ T cells but is not found in purified CD34+ hematopoietic progenitor cells in most patients on antiretroviral therapy. J Infect Dis 2012, 205:1014-1018.

77. Josefsson L, Eriksson S, Sinclair E, Ho T, Killian M, Epling L, Shao W, Lewis B, Bacchetti P, Loeb L, Custer J, Poole L, Hecht FM, Palmer S: Hematopoietic precursor cells isolated from patients on long-term suppressive HIV therapy did not contain HIV-1 DNA. J Infect Dis 2012, 206:28-34

78. McNamara LA, Collins KL: Hematopoietic stem/precursor cells as HIV reservoirs. Curr Opin HIV AIDS 2011, 6:43-48.

79. Jordan A, Bisgrove D, Verdin E: HIV reproducibly establishes a latent infection after acute infection of T cells in vitro. EMBO J 2003 22:1868-1877. 
80. Kim YK, Bourgeois CF, Pearson R, Tyagi M, West MJ, Wong J, Wu S-Y, Chiang C-M, Karn J: Recruitment of TFIIH to the HIV LTR is a rate-limiting step in the emergence of HIV from latency. EMBO J 2006, 25:3596-3604.

81. Duverger A, Jones J, May J, Bibollet-Ruche F, Wagner FA, Cron RQ, Kutsch O: Determinants of the establishment of human immunodeficiency virus type 1 latency. J Virol 2009, 83:3078-3093.

82. Donahue DA, Kuhl BD, Sloan RD, Wainberg MA: The viral protein Tat can inhibit the establishment of HIV-1 latency. J Virol 2012, 86:3253-3263.

83. Weinberger LS, Burnett JC, Toettcher JE, Arkin AP, Schaffer DV: Stochastic gene expression in a lentiviral positive-feedback loop: HIV-1 Tat fluctuations drive phenotypic diversity. Cell 2005, 122:169-182

84. Burnett JC, Miller-Jensen K, Shah PS, Arkin AP, Schaffer DV: Control of stochastic gene expression by host factors at the HIV promoter. PLOS Pathog 2009, 5:e1000260.

85. Micheva-Viteva S, Pacchia AL, Ron Y, Peltz SW, Dougherty JP: Human immunodeficiency virus type 1 latency model for high-throughput screening. Antimicrob Agents Chemother 2005, 49:5185-5188.

86. Jeeninga RE, Westerhout EM, van Gerven ML, Berkhout B: HIV-1 latency in actively dividing human T cell lines. Retrovirology 2008, 5:37.

87. Perelson AS, Neumann AU, Markowitz M, Leonard JM, Ho DD: HIV-1 dynamics in vivo: virion clearance rate, infected cell life-span, and viral generation time. Science 1996, 271:1582-1586

88. Coiras M, López-Huertas MR, Pérez-Olmeda M, Alcamí J: Understanding HIV-1 latency provides clues for the eradication of long-term reservoirs. Nat Rev Microbio/ 2009, 7:798-812

89. Siliciano RF, Greene WC: HIV Latency. Cold Spring Harb Perspect Med 2011, 1:a007096

90. Mbonye U, Karn J: Control of HIV latency by epigenetic and nonepigenetic mechanisms. Curr HIV Res 2011, 9:554-567.

91. Margolis DM: Mechanisms of HIV latency: an emerging picture of complexity. Curr HIV/AIDS Rep 2010, 7:37-43.

92. Chomont N, DaFonseca S, Vandergeeten C, Ancuta P, Sékaly R-P. Maintenance of CD4+ T-cell memory and HIV persistence: keeping memory, keeping HIV. Curr Opin HIV AIDS 2011, 6:30-36.

93. Schröder ARW, Shinn P, Chen H, Berry C, Ecker JR, Bushman F: HIV-1 integration in the human genome favors active genes and local hotspots. Cell 2002, 110:521-529.

94. Wang GP, Ciuffi A, Leipzig J, Berry CC, Bushman FD: HIV integration site selection: analysis by massively parallel pyrosequencing reveals association with epigenetic modifications. Genome Res 2007, 17:1186-1194.

95. Vatakis DN, Kim S, Kim N, Chow SA, Zack JA: Human immunodeficiency virus integration efficiency and site selection in quiescent CD4+ T cells. J Virol 2009, 83:6222-6233.

96. Brady T, Agosto LM, Malani N, Berry CC, O'Doherty U, Bushman F: HIV integration site distributions in resting and activated CD4+ T cells infected in culture. AIDS 2009, 23:1461-1471.

97. Shan L, Yang H-C, Rabi SA, Bravo HC, Shroff NS, Irizarry RA, Zhang H, Margolick JB, Siliciano JD, Siliciano RF: Influence of host gene transcription level and orientation on HIV-1 latency in a primary-cell model. J Virol 2011, 85:5384-5393.

98. Lewinski MK, Bisgrove D, Shinn P, Chen H, Hoffmann C, Hannenhalli S, Verdin E, Berry CC, Ecker JR, Bushman FD: Genome-wide analysis of chromosomal features repressing human immunodeficiency virus transcription. J Virol 2005, 79:6610-6619.

99. Han Y, Lassen K, Monie D, Sedaghat AR, Shimoji S, Liu X, Pierson TC Margolick JB, Siliciano RF, Siliciano JD: Resting CD4+ T cells from human immunodeficiency virus type 1 (HIV-1)-infected individuals carry integrated HIV-1 genomes within actively transcribed host genes. J Virol 2004, 78:6122-6133.

100. Shearwin KE, Callen BP, Egan JB: Transcriptional interference-a crash course. Trends Genet 2005, 21:339-345.

101. Mazo A, Hodgson JW, Petruk S, Sedkov Y, Brock HW: Transcriptional interference: an unexpected layer of complexity in gene regulation. J Cell Sci 2007, 120:2755-2761.

102. Han Y, Lin YB, An W, Xu J, Yang H-C, O'Connell K, Dordai D, Boeke JD, Siliciano JD, Siliciano RF: Orientation-dependent regulation of integrated HIV-1 expression by host gene transcriptional readthrough. Cell Host Microbe 2008, 4:134-146

103. Lenasi T, Contreras $X$, Peterlin BM: Transcriptional interference antagonizes proviral gene expression to promote HIV latency. Cell Host Microbe 2008, 4:123-133.
104. Gallastegui E, Millán-Zambrano G, Terme J-M, Chávez S, Jordan A: Chromatin reassembly factors are involved in transcriptional interference promoting HIV latency. J Virol 2011, 85:3187-3202.

105. Ganesh L, Burstein E, Guha-Niyogi A, Louder MK, Mascola JR, Klomp LWJ, Wijmenga C, Duckett CS, Nabel GJ: The gene product Murr1 restricts HIV1 replication in resting CD4+ lymphocytes. Nature 2003, 426:853-857.

106. Duverger A, Wolschendorf F, Zhang M, Wagner F, Hatcher B, Jones J, Cron $R Q$, van der Sluis $R M$, Jeeninga RE, Berkhout $B$, Kutsch O: An AP-1 binding site in the enhancer/core element of the HIV-1 promoter controls the ability of HIV-1 to establish latent infection. J Virol 2012, [Epub ahead of print]

107. Vandergeeten C, Fromentin R, Chomont N: The role of cytokines in the establishment, persistence and eradication of the HIV reservoir. Cytokine Growth Factor Rev 2012, 23:143-149.

108. Zhou Q, Yik JHN: The Yin and Yang of P-TEFb regulation: implications for human immunodeficiency virus gene expression and global control of cell growth and differentiation. Microbiol Mol Biol Rev 2006, 70:646-659.

109. Budhiraja S, Famiglietti M, Bosque A, Planelles V, Rice AP: Cyclin T1 and CDK9 T-loop phosphorylation are downregulated during establishment of HIV-1 latency in primary resting memory CD4+ T cells. J Virol 2012, 87(2):1211-1220.

110. Jenuwein T, Allis CD: Translating the histone code. Science 2001, 293:1074-1080.

111. du Chéné I, Basyuk E, Lin Y-L, Triboulet R, Knezevich A, Chable-Bessia C, Mettling C, Baillat V, Reynes J, Corbeau P, Bertrand E, Marcello A, Emiliani S, Kiernan R, Benkirane M: Suv39H1 and HP1gamma are responsible for chromatin-mediated HIV-1 transcriptional silencing and post-integration latency. EMBO J 2007, 26:424-435.

112. Marban C, Suzanne S, Dequiedt F, de Walque S, Redel L, Van Lint C, Aunis D, Rohr O: Recruitment of chromatin-modifying enzymes by CTIP2 promotes HIV-1 transcriptional silencing. EMBO J 2007, 26:412-423.

113. Tyagi $M$, Karn J: CBF-1 promotes transcriptional silencing during the establishment of HIV-1 latency. EMBO J 2007, 26:4985-4995.

114. Pearson R, Kim YK, Hokello J, Lassen K, Friedman J, Tyagi M, Karn J: Epigenetic silencing of human immunodeficiency virus (HIV) transcription by formation of restrictive chromatin structures at the viral long terminal repeat drives the progressive entry of HIV into latency. J Virol 2008, 82:12291-12303.

115. Friedman J, Cho W-K, Chu CK, Keedy KS, Archin NM, Margolis DM, Karn J: Epigenetic silencing of HIV-1 by the histone $\mathrm{H} 3$ lysine 27 methyltransferase enhancer of Zeste 2. J Virol 2011, 85:9078-9089.

116. Kauder SE, Bosque A, Lindqvist A, Planelles V, Verdin E: Epigenetic regulation of HIV-1 latency by cytosine methylation. PLOS Pathog 2009, 5:e1000495.

117. Rafati H, Parra M, Hakre S, Moshkin Y, Verdin E, Mahmoudi T: Repressive LTR nucleosome positioning by the BAF complex is required for HIV latency. PLOS Biol 2011, 9:e1001206.

118. Sobhian B, Laguette N, Yatim A, Nakamura M, Levy Y, Kiernan R, Benkirane M: HIV-1 Tat assembles a multifunctional transcription elongation complex and stably associates with the 7SK snRNP. Mol Cell 2010, 38:439-451.

119. He N, Liu M, Hsu J, Xue Y, Chou S, Burlingame A, Krogan NJ, Alber T, Zhou Q: HIV-1 Tat and host AFF4 recruit two transcription elongation factors into a bifunctional complex for coordinated activation of HIV-1 transcription. Mol Cell 2010, 38:428-438.

120. Yukl S, Pillai S, Li P, Chang K, Pasutti W, Ahlgren C, Havlir D, Strain M Günthard H, Richman D, Rice AP, Daar E, Little S, Wong JK: Latentlyinfected CD4+ T cells are enriched for HIV-1 Tat variants with impaired transactivation activity. Virology 2009, 387:98-108.

121. Weinberger LS, Dar RD, Simpson ML: Transient-mediated fate determination in a transcriptional circuit of HIV. Nat Genet 2008, 40:466-470.

122. Huang J, Wang F, Argyris E, Chen K, Liang Z, Tian H, Huang W, Squires K, Verlinghieri G, Zhang H: Cellular microRNAs contribute to HIV-1 latency in resting primary CD4+ T lymphocytes. Nat Med 2007, 13:1241-1247.

123. Chable-Bessia C, Meziane O, Latreille D, Triboulet R, Zamborlini A, Wagschal A, Jacquet J-M, Reynes J, Levy Y, Saib A, Bennasser Y, Benkirane M: Suppression of HIV-1 replication by microRNA effectors. Retrovirology 2009, 6:26.

124. Chiang K, Rice AP: MicroRNA-Mediated Restriction of HIV-1 in Resting CD4(+) T Cells and Monocytes. Viruses 2012, 4:1390-1409. 
125. Li XD, Moore B, Cloyd MW: Gradual shutdown of virus production resulting in latency is the norm during the chronic phase of human immunodeficiency virus replication and differential rates and mechanisms of shutdown are determined by viral sequences. Virology 1996, 225:196-212

126. van der Sluis RM, Pollakis $G$, van Gerven ML, Berkhout B, Jeeninga RE: Latency profiles of full length HIV-1 molecular clone variants with a subtype specific promoter. Retrovirology 2011, 8:73.

127. Trono D, Van Lint C, Rouzioux C, Verdin E, Barré-Sinoussi F, Chun T-W, Chomont N: HIV persistence and the prospect of long-term drug-free remissions for HIV-infected individuals. Science 2010, 329:174-180.

128. Evans VA, Khoury G, Saleh S, Cameron PU, Lewin SR: HIV persistence: Chemokines and their signalling pathways. Cytokine Growth Factor Rev 2012, 23:151-157.

129. Strain MC, Little SJ, Daar ES, Havlir DV, Günthard HF, Lam RY, Daly OA, Nguyen J, Ignacio CC, Spina CA, Richman DD, Wong JK: Effect of treatment, during primary infection, on establishment and clearance of cellular reservoirs of HIV-1. In J Infect Dis 2005, 191:1410-1418.

130. Ananworanich J, Schuetz A, Vandergeeten C, Sereti I, de Souza M, Rerknimitr R, Dewar R, Marovich M, van Griensven F, Sekaly R, Pinyakorn S, Phanuphak N, Trichavaroj R, Rutvisuttinunt W, Chomchey N, Paris R, Peel S, Valcour V, Maldarelli F, Chomont N, Michael N, Phanuphak P, Kim JH, RV254/SEARCH 010 Study Group: Impact of multi-targeted antiretroviral treatment on gut $\mathrm{T}$ cell depletion and HIV reservoir seeding during acute HIV infection. PLoS One 2012, 7:e33948.

131. Chun T-W, Justement JS, Moir S, Hallahan CW, Maenza J, Mullins IJ, Collier AC, Corey L, Fauci AS: Decay of the HIV reservoir in patients receiving antiretroviral therapy for extended periods: implications for eradication of virus. J Infect Dis 2007, 195:1762-1764.

132. Gianella S, Wyl von V, Fischer M, Niederoest B, Battegay M, Bernasconi E, Cavassini M, Rauch A, Hirschel B, Vernazza P, Weber R, Joos B, Günthard HF, Swiss HIV Cohort Study: Effect of early antiretroviral therapy during primary HIV-1 infection on cell-associated HIV-1 DNA and plasma HIV-1 RNA. Antivir Ther (Lond) 2011, 16:535-545.

doi:10.1186/1742-4690-10-11

Cite this article as: Donahue and Wainberg: Cellular and molecular mechanisms involved in the establishment of HIV-1 latency. Retrovirology 2013 10:11

\section{Submit your next manuscript to BioMed Central and take full advantage of:}

- Convenient online submission

- Thorough peer review

- No space constraints or color figure charges

- Immediate publication on acceptance

- Inclusion in PubMed, CAS, Scopus and Google Scholar

- Research which is freely available for redistribution 